\title{
A Note on Russia's Merchandise Balance and Balance of Payments During the Industrialization Era
}

Russia's balance of trade (torgovyi balans) and balance of payments (raschetnyi balans) were matters of great concern to the tsarist government before and after the introduction of the gold standard in $1897 . .^{1}$ Tsarist officials feared that the gold reserves required to maintain (or to go on) the gold standard would be lost if payments abroad exceeded receipts. ${ }^{2}$ Moreover, there was concern over the potential loss of political and economic independence if the government had to borrow abroad regularly in order to cover international payments deficits. Russia's foreign policy toward France and Germany was affected significantly by this consideration. ${ }^{3}$ Thus, considerable importance rested on the reported estimates of these two balances."

Although the individual estimates made by tsarist, Soviet, and Western authors (OI', Vyshnegradskii, Engeev, Pasvolsky and Moulton, Gregory) differ, they agree in one respect-namely, that despite a positive merchandise balance from the 1880s onward, Russia's balance of payments was typically passive because of two significant negative items: large interest and dividend payments abroad and substantial net expenditures by Russian tourists abroad. Considerable research has gone into estimating interest and dividend accounts, ${ }^{5}$ and Russia's

1. By "balance of payments" I mean net foreign investment or, in other words, the balance of trade including invisibles and services, such as interest and dividend payments abroad and tourist expenditures abroad. The conceptual definition is the one adopted by the League of Nations in 1938. It is described in L. I. Frei, Osnovnye problemy mezhdunarodnykh raschetov (Moscow: Mezhdunarodnaia kniga, 1945), pp. 30-33.

2. For a clear statement of contemporary concerns at the time of the introduction of the gold standard, see S. F. Sharapov, Tsifrovoi analiz raschetnogo balansa Rossii za 15-letie (St. Petersburg : Bernshtein, 1897), introduction.

3. For a discussion of the foreign policy implications of the Russian balance of payments, see Bernd Bonwetsch, "Handelspolitik und Industrialisierung: Zur aussenwirtschaftlichen Abhängigkeit Russlands," in D. Geyer, ed., Wirtschaft und Gesellschaft im vorrevolutionären Russland (Cologne: Kiepenheur und Witsch, 1975), p. 277-301.

4. I have described the various estimates of the Russian balance of payments-by O1', Vyshnegradskii, Migulin, Engeev, Pasvolsky and Moulton-in Paul R. Gregory, "The Russian Balance of Payments, the Gold Standard, and Monetary Policy: A Historical Example of Foreign Capital Movements," Journal of Economic History, 39, no. 2 (June 1979).

5. The major work in this area is P. V. O1', Inostrannye kapitaly $v$ narodnom khoziaistve dovoennoi Rossii: Materialy dlia izuchemiia estestvennykh proigvoditel'nykh sil SSSR (Leningrad, 1925). Other important works are: A. L. Vainshtein, Narodnoe bogatstvo i narodnokhoziaistvennoe nakoplenie predrevoliutsionnoi Rossii (Moscow: Gosstatizdat, 
annual net payments abroad can be estimated with some degree of precision. ${ }^{6}$ Net tourist expenditures abroad cannot be estimated with the same accuracy, although the various estimates are surprising for their conformity. ${ }^{7}$ The consensus of opinion is that tourist expenditures were indeed substantial, ${ }^{8}$ and, combined with net interest and dividend payments, were sufficient to outweigh the positive merchandise balances of the late nineteenth and early twentieth centuries and thus necessitate either an outflow of gold or continued foreign borrowing.

The major challenge to this judgment is John Sontag's article, which appeared in Slavic Review in 1968. His conclusions contradict a wide body of established literature, both historical and contemporary. ${ }^{9}$ It is my opinion, however, that Sontag's conclusions are wrong for reasons indicated in the discussion that follows. Although this essay follows Sontag's paper by a decade, I believe the points raised by Sontag to be sufficiently important for understanding Russian economic history to warrant a reexamination of the payments issue.

Sontag's main contention is that the Russian merchandise balance was much more positive than official figures indicate. He believes this underestimation to be the consequence of a persistent downward bias in the official Russian export figures, combined with a persistent (but less serious) upward bias in Russia's official import figures. Sontag argues that the understatement of the positive merchandise balance was sufficiently serious, so that the actual positive merchandise balance was large enough to outweigh the passive interest, dividend, and tourist expenditure accounts. From this, Sontag goes on to draw far-reaching conclusions concerning Russian foreign policy. Since I am not a historian, I cannot presume to comment upon the foreign policy inferences. I can, however, attempt to deal with Sontag's conclusions concerning the balance of payments. If Sontag's contention is correct, then the reader must confront the following riddle: Given the Finance Ministry's great effort to present an image of financial stability to the rest of the world, why would it permit its statistical department to publish official trade figures which understated the positive merchandise balance?

The possibility of an underestimation of the Russian merchandise balance is not a new theme in the literature. Between 1896 and 1902, V. I. Pokrovskii, the talented and longstanding director of the statistical department of the customs office of the Finance Ministry, conducted research comparing market and customs valuations of imports and exports. ${ }^{10} \mathrm{He}$ was particularly interested in the possibility of an undervaluation of exports relative to market valuations. Although

$1960)$; V. I. Bovykin, "K voprosu o roli inostrannogo kapitala v Rossii," Vestnik Moskovskogo universiteta, 1964, no. 1, pp. 55-83.

6. For an attempt to establish confidence intervals for Russian foreign indebtedness, see Bovykin, " $\mathrm{K}$ voprosu o roli inostrannogo kapitala."

7. See T. K. Engeev, "O platezhnom balanse dovoennoi Rossii," Vestnik finansov, 1928 , no. 5, pp. 77 and 82.

8. The available estimates place net tourist expenditures at approximately sixty million rubles in the early $1890 \mathrm{~s}$, about one hundred million rubles in the early twentieth century, and around two hundred million rubles in 1913.

9. John Sontag, "Tsarist Debts and Tsarist Foreign Policy," Slavic Review, 27, no. 4 (December 1968) : 529-41.

10. V. I. Pokrovskii, ed., Sbornik svedenii po istorii $i$ statistike vneshnei torgovli Rossii, vol. 1 (St. Petersburg: Departament tamozhennykh sborov, 1902). 
this is not stated, I suspect that Pokrovskii was hoping to find that the official figures had understated the positive merchandise balance. In an early study (1896), Pokrovskii stated that Russian exports may have been undervalued by as much as 15 percent, ${ }^{11}$ but his definitive study did not appear until $1902 .{ }^{12}$ Indeed, many of Margaret Miller's and Sontag's criticisms of the official trade statistics, which were published annually in the Survey of Foreign Trade (Obzor vneshnei torgovli) by Pokrovskii's own department, ${ }^{13}$ are based upon Pokrovskii's 1902 study. This is curious because, if anything, Pokrovskii's work failed to reveal serious discrepancies between market and customs evaluations of Russian exports. This will be discussed in more detail below.

Sontag's conclusion that the official Obzor trade figures overstated Russian imports and understated exports rests on two types of evidence. On the import side, he relies on evidence provided by Margaret Miller's 1926 study, ${ }^{14}$ and he strongly emphasizes her general conclusions concerning the unreliability of Russian trade statistics. Miller contends that the customs valuation of Russian imports tended to be systematically overvalued relative to their market valuation. To prove this point, Miller cites isolated cases in which customs import valuations appeared to be exaggerated, such as customs prices of steel rails. Her explanation for this phenomenon is that importers consistently overstated values of imported items to customs officials in order to obtain higher market prices later when these goods were sold on the Russian market.

This evidence is less than convincing for a number of reasons. First, Miller supplies no evidence that such overvaluations were widespread and systematic. Second, the payoff from attempting to raise the narket price of an imported commodity by exaggerating its market value to customs officials was likely to be small. ${ }^{15}$ Insofar as the market would establish the market price and not the customs valuation, there would not seem to be much of a relationship between the degree of exaggeration of the customs valuation and the eventual market price. A possible exception may have been the case of the state (such as steel rails) as the final purchaser, ${ }^{16}$ but even here exaggerated customs valuations would probably have had little effect, because the state, along with everyone else, was well aware of the cost of steel rails in foreign markets as well as transport costs. ${ }^{17}$

The strength of Sontag's argument, however, rests in his assertion that the major bias in the official figures was in the understatement of Russian exports, not the overstatement of imports. In fact, some of the evidence he presents tends to indicate that import valuations were relatively accurate. This position is con-

11. This result is cited by L. Pasvolsky and H. G. Moulton, Russian Debts and Russian Reconstruction (New York: McGraw-Hill, 1924), appendix 4, p. 187.

12. Pokrovskii, Sbornik svedenii, pp. 11-35.

13. Obzor vneshnei torgovli Rossii po evropeiskoi $i$ aziatskoi granitsam za ... god, annual ed., 28 vols. (St. Petersburg: Departament tamozhennykh sborov, 1885-1913), 5:5 and 14.

14. Margaret S. Miller, The Economic Development of Russia 1905-1914, 2nd ed. (London: Frank Cass, 1967), pp. 40-45.

15. Tariffs were normally on weight not value; therefore, an exaggerated customs valuation would not raise the tariff obligations of the importer.

16. Major purchases of military equipment by the War Ministry did not enter into the import data, but were handled separately.

17. These prices were quoted regularly in such commercial publications as Vestnik finansov and Svod tovarnykh tsen. 
sistent with the contemporary opinion, cited by Pasvolsky and Moulton, ${ }^{18}$ that the bias, if any, lay in the estimation of exports, since customs officials were much more interested in measuring imports accurately than in evaluating exports properly. Thus, I conclude (and I believe Sontag would agree) that any serious understatement of the positive merchandise balance would have to be attributable to the understatement of Russian exports.

Sontag uses two types of evidence to support his contention that Russian exports were seriously undervalued. The first is the evidence, provided by Pokrovskii, ${ }^{19}$ and cited by Miller, that the customs prices of Russian cereal exports (approximately one-half of the value of total exports in 1897, for example) were not necessarily the same as domestic market prices or foreign market prices. In fact, Pokrovskii shows that, in some years, the deviations were substantial. But it is important to note that, at least for the period investigated by Pokrovskii (1851-97), there was no uniform tendency for the customs price (tamozhennaia otsenka) to understate domestic market prices: as measured by Odessa market prices, in some years it exceeded the market price, in other years it was less than the market price. The Pokrovskii study did show that foreign cereal prices on Russia's principal export markets-London and Germany-were consistently above both domestic market prices and customs prices in Russia. For example, the price of cereals (wheat, rye, barley) on the London and Königsberg markets averaged 26 percent more (weighted by value of exports) than Russian customs prices during the period 1886-97, but such differences are to be expected and can be accounted for by transport, brokerage, storage, and insurance charges and by German tariffs on Russian cereals. ${ }^{20}$ That London or German wheat prices exceeded Russian prices fails to say anything about the validity of Russian customs prices.

In regard to Pokrovskii's comparison of domestic market prices and customs prices, it should be pointed out that, using Odessa market prices alone, one finds that between 1885 and 1897 customs prices of cereals were 4 percent below Odessa prices (both weighted by value of exports). Applying the same procedure to an average of market prices in major Russian port and border cities (189097), one sees that customs prices averaged 4 percent above market prices. ${ }^{21}$

Miller's own explanation of why exports were consistently understated-a contention not at all supported by the Pokrovskii study-is that exporters paid a fixed percentage of the customs price as a fee for the customs valuation and thus had an incentive to understate the value of the exported commodity. I find this

18. Pasvolsky and Moulton, Russian Debts, pp. 186-87.

19. Pokrovskii, Sbornik svedenii, p. 35.

20. According to Pokrovskii's data, the London wheat price was 13 percent above the customs price, while Königsberg prices of rye and barley were generally 50 percent above customs prices. The higher German price differentials reflect Germany's restrictive tariff policies toward Russian cereals; German tariff policy is discussed by Bonwetsch, "Handelspolitik und Industrialisierung," pp. 280-94. The London price differential is consistent with independent data on transport costs cited by Paul Gregory, "Russian National Income in 1913-Some Insights Into Russian Economic Development," Quarterly Journal of Economics, 90, no. 3 (August 1976), statistical appendix. The cost of transporting grain was about four and a half rubles per ton in 1913, or approximately 10 percent of the domestic price of grain products (weighted by share of exports). Commissions and insurance fees would then add on additional costs to these shipping charges.

21. Pokrovskii, Sbornik svedenii, pp. 14 and 35. 
argument unconvincing because the cost of the customs valuation was likely to be minimal and would be countered by the state's desire to collect the fee. ${ }^{22}$ Second, customs officials had easy access to information on current market prices of food products and raw materials, most of which were quoted on Russian commodity exchanges. The more probable explanations for the (nonsystematic) divergences between customs and market prices observed by Pokrovskii are the nonintegration of the Russian wheat market, the lags between purchase and shipment, and the considerable seasonal fluctuations in cereal prices. ${ }^{23}$ Moreover, the customs price was levied at the moment of export and would thus be a weighted average with monthly shipments serving as weights. The market price quotations cited by Pokrovskii, however, were simple unweighted monthly averages. This point was not overlooked even by Pokrovskii and it can explain many of the differences between market and customs prices.

Sontag's second source of evidence against the reliability of the Obzor figures is that they deviate from totals compiled by adding up exports to and from Russia cited by foreign statistical authorities. The Department of Customs Collections itself was cognizant of these differences and published comparisons of its own statistics with aggregates of Russian exports and imports compiled from the foreign trade statistics of other countries. Such comparisons show that the value of imports reported as being received from Russia by foreign countries typically exceeded the value of Russian exports reported by the Obzor series. On the other hand, the value of exports reported by foreign countries as being sent to Russia falls short of the Russian import figure cited by the Obzor series. For 1908, for example, the value of imports received by the twenty major trading countries from Russia was 1,408 million rubles, as compared to the Obzor export figure of 930 million rubles; the value of exports to Russia reported by these countries was 738 million rubles as compared with the Obzor import figure of 873 million rubles. ${ }^{24}$ Even after adjustment for transport and brokerage costs, Sontag concludes from this evidence that Russian exports were grossly undervalued in the Obzor series.

I find Sontag's arguments unpersuasive. As pointed out by Russian authorities and much later by Bonwetsch, ${ }^{25}$ one cannot rely upon aggregations of the foreign trade statistics of other countries because there would be considerable double-counting of imports from Russia. Some countries (Holland, for example) counted Russian goods shipped through Dutch ports to third countries as exports received from Russia; the same goods then entered the statistics of the third

22. I was unable to find information on the caleulation of the evaluation fee, but I assume it to be modest. Even though it was likely to be modest, the possibility that it would represent a nonsignificant share of the exporter's margin cannot be ruled out. Moreover, it does not rule out the possibility of corruption on the part of customs officials. However, I believe that the most important check on understated customs evaluations was the ready information on market prices, as I argue in the text.

23. The most detailed study of regional price variation is I. Koval'chenko and L. Milov, $V$ serossiiskii agrarnyi rynok, XVIII-nachalo XX veka (Moscow: Nauka, 1974). For data on seasonal price differences, see Svod tovarnykh tsen, published annually by the Ministry of Trade and Industry.

24. Obzor vneshnei torgovli Rossii po evropeiskoi $i$ aziatskoi granitsam za 1908 god (St. Petersburg: Departament tamozhennykh sborov, 1910), pp. 5-6.

25. Bernd Bonwetsch, "Das ausländische Kapital in Russland," Jahrbücher für Geschichte Osteuropas, 22, no. 3 (1974): 419. 
country also as exports received from Russia. If figures from the two countries are added together, exports received from Russia are overstated. Only the exporting country can unambiguously avoid this type of double-counting. ${ }^{28}$

Sontag recognizes that part of the discrepancy between the Obzor figures and the foreign export figures must be attributed to the fact that the Obzor figures are f.o.b. and the foreign figures are c.i.f. charges. He argues that, if one makes a liberal adjustment for commission, insurance, and freight (25 percent of the c.i.f. value), only one-half of the discrepancy between the Obzor and foreign export figures is eliminated. If, however, one now includes the effect of doublecounting (and a major study of the foreign trade statistics of the other countries would be required to establish the magnitude of the double-counting adjustment), it is not unlikely that the rest of the discrepancy will be explained. Pokrovskii's finding of nonsystematic discrepancies between customs and market prices supports this position.

Until this matter can be resolved empirically, I prefer to rely on the logical argument that it is quite unlikely for customs officials to have delivered estimates of Russian exports which were biased heavily downward. As noted above, the market prices of food products and raw materials were well known. An important policy factor-namely, that the Ministry of Finance, of which the customs office was a part, was at that time making every effort to present an image of financial stability to the rest of the world-also supports this contention, since it is unlikely that the Ministry of Finance would have tolerated biased estimates of Russian imports and exports which could damage this image. In fact, the more probable temptation would have been to reverse the bias and overstate the value of exports and understate the value of imports. Thus, the most logical conclusion at this point is that the figures in the official Obzor series are not seriously biased in the direction of underestimating Russian exports or overestimating imports and are sufficiently reliable for use in estimating the Russian' balance of payments. ${ }^{27}$

If one accepts my conclusion that the official Russian merchandise balance figures are not systematically biased, it is necessary to return to the traditional conclusion that the Russian balance of payments was passive in the late nineteenth and early twentieth centuries. Table 1 shows the official Obzor export and import figures for the period 1885-1913. It is evident from the figures that the merchan-

26. It should be noted that the Obzor series does indeed net out goods shipped through Russia to third countries by counting only commodities released for domestic consumption; whereas the statistics of other countries could likely include double-counting. Moreover, as the figures for 1908 indicate, the difference between foreign aggregate and Obzor import valuations is fairly small, and is probably accounted for by transport costs (the foreign figures are f.o.b. and the Russian import figures are c.i.f.) plus some double-counting. Thus, in my view, the foreign data on exports to Russia generally support the validity of the Obzor import series.

27. I share this judgment with B. V. Avilov, the compiler of the statistical appendix on Russian economic development for the Granat encyclopedia. Avilov argued that prerevolutionary Russian foreign trade statistics were quite reliable, an enthusiasm he did not hold for other official statistical series (B. V. Avilov, ed., appendix to "Ekonomicheskoe razvitie Rossii v XIX i v nachale XX veka," Entsiklopedicheskii slovar' russkogo bibliograficheskogo instituta Granat, 7th ed., vol. 36, pp. 4 and 66). This position is also supported by a major study of the reliability of foreign trade statistics conducted in the Soviet Union by Dvoretskii (E. V. Dvoretskii, Rossiiskaia statistika vneshnei torgovli kak istoricheskii istochnik [Moscow: Akademiia nauk, Institut istorii SSSR, 1974]). 
Table 1. Russian Exports and Imports, Including Silver, and Net Merchandise Balance, 1885-1913 (in millions of credit rubles)

\begin{tabular}{|c|c|c|c|c|c|c|c|}
\hline Year & Exportsa & $\begin{array}{c}\text { (3) } \\
\text { Silver } \\
\text { Exports }\end{array}$ & $\begin{array}{c}\text { (4) } \\
\text { Total } \\
\text { Exports }\end{array}$ & Imports ${ }^{A}$ & $\begin{array}{c}(6) \\
\text { Silver } \\
\text { Imports }\end{array}$ & $\begin{array}{c}\text { (7) } \\
\text { Total } \\
\text { Imports }\end{array}$ & $\begin{array}{c}(8) \\
\text { Merchandise } \\
\text { Balance } \\
(7-4)\end{array}$ \\
\hline $\begin{array}{l}1885 \\
1886 \\
1887 \\
1888 \\
1889 \\
1890 \\
1891 \\
1892 \\
1893 \\
1894 \\
1895 \\
1896 \\
1897 \\
1898 \\
1899 \\
1900 \\
1901 \\
1902 \\
1903 \\
1904 \\
1905 \\
1906 \\
1907 \\
1908 \\
1909 \\
1910 \\
1911 \\
1912 \\
1913\end{array}$ & $\begin{array}{r}538 \\
484 \\
617 \\
784 \\
751 \\
692 \\
707 \\
476 \\
599 \\
669 \\
689 \\
689 \\
727 \\
733 \\
627 \\
716 \\
762 \\
860 \\
1,001 \\
1,006 \\
1,077 \\
1,095 \\
1,053 \\
1,998 \\
1,428 \\
1,449 \\
1,591 \\
1,519 \\
1,520\end{array}$ & $\begin{array}{r}3 \\
2 \\
3 \\
4 \\
3 \\
4 \\
5 \\
4 \\
7 \\
7 \\
1 \\
2 \\
5 \\
3 \\
2 \\
18 \\
4 \\
6 \\
2 \\
35 \\
40 \\
7 \\
1 \\
4\end{array}$ & $\begin{array}{r}541 \\
486 \\
620 \\
792 \\
754 \\
696 \\
712 \\
480 \\
606 \\
676 \\
690 \\
691 \\
732 \\
736 \\
629 \\
734 \\
766 \\
866 \\
1,003 \\
1,041 \\
1,117 \\
1,102 \\
1,054 \\
2,002 \\
1,428 \\
1,449 \\
1,591 \\
1,519 \\
1,520\end{array}$ & $\begin{array}{r}435 \\
427 \\
400 \\
386 \\
432 \\
407 \\
372 \\
400 \\
450 \\
554 \\
526 \\
590 \\
560 \\
618 \\
651 \\
626 \\
593 \\
599 \\
682 \\
651 \\
635 \\
801 \\
847 \\
913 \\
906 \\
1,084 \\
1,162 \\
1,172 \\
1,374\end{array}$ & $\begin{array}{c}4 \\
5 \\
4 \\
11 \\
9 \\
7 \\
11 \\
9 \\
18 \\
22 \\
14 \\
29 \\
47 \\
31 \\
34 \\
29 \\
9 \\
6 \\
7 \\
19 \\
57 \\
16 \\
9 \\
12^{\mathrm{b}} \\
12^{\mathrm{b}} \\
(12)^{\mathrm{b}} \\
13^{\mathrm{b}} \\
18^{\mathrm{b}} \\
18^{\mathrm{b}}\end{array}$ & $\begin{array}{r}439 \\
432 \\
404 \\
397 \\
441 \\
414 \\
383 \\
409 \\
468 \\
576 \\
540 \\
619 \\
607 \\
645 \\
685 \\
645 \\
602 \\
605 \\
689 \\
670 \\
692 \\
817 \\
856 \\
925 \\
918 \\
1,096 \\
1,175 \\
1,190 \\
1,392\end{array}$ & $\begin{array}{l}+102 \\
+54 \\
+216 \\
+395 \\
+313 \\
+282 \\
+329 \\
+71 \\
+138 \\
+100 \\
+150 \\
+72 \\
+125 \\
+91 \\
+56 \\
+71 \\
+164 \\
+261 \\
+314 \\
+371 \\
+425 \\
+285 \\
+198 \\
+77 \\
+510 \\
+353 \\
+416 \\
+329 \\
+128\end{array}$ \\
\hline
\end{tabular}

a Excluding silver.

b Net figures.

Sources: Obzor vneshnei torgovli Rossii po evropeiskoi $i$ aziatskoi granitsam za . . . god [1885-1913 gg.], annual ed., 28 vols. (St. Petersburg: Departament tamozhennykh sborov, 1885-1913); V. I. Pokrovskii, ed., Sbornik svedenii po istorii $i$ statistike vneshnei torgovli Rossii, vol. 1 (St. Petersburg: Departament tamozhennykh sborov, 1902). The silver (net) import figures for the years 1911-13 are taken from A. I. Bukovetskii, "'Svobodnaia nalichnost' ' i zolotoi zapas tsarskogo pravitel'stva v kontse XIX-nachale XX v.," in M. P. Viatkin, ed., Monopolii i inostrannyi kapital v Rossii (Moscow: Nauka, 1962), p. 374.

dise balance was consistently positive (except in 1899), and an examination of period averages (see table 2 , column 2 ) indicates that the merchandise surplus averaged 181 million rubles annually in 1885-97, 205 million rubles in 1897-1906, and 287 million rubles for 1906-13. In order for the balance of payments (the balance on current account) to be positive, the merchandise surplus would have to be larger than the passive service accounts, such as interest and dividend payments abroad and net tourist expenditures abroad. As table 2 indicates, net service expenditures consistently outweighed the positive merchandise balance, and, in fact, the balance-of-payments deficit grew as a percentage of the merchandise 
Table 2. Approximate Russian Balance of Payments (Net Foreign Investment), Annual Averages (in millions of credit rubles)

\begin{tabular}{|c|c|c|c|c|c|}
\hline Period & $\begin{array}{l}\text { Merchandise } \\
\text { Surplus }\end{array}$ & $\begin{array}{c}(3) \\
\text { Net Interest } \\
\text { Payments, } \\
\text { Imperial } \\
\text { Government }\end{array}$ & $\begin{array}{c}(4) \\
\text { Other } \\
\text { Interest and } \\
\text { Dividend } \\
\text { Payments }\end{array}$ & $\begin{array}{l}\text { Net Tourist } \\
\text { Expenditures }\end{array}$ & $\begin{array}{c}(6) \\
\text { Approximate } \\
\text { Balance } \\
(2+3+4+5)\end{array}$ \\
\hline $\begin{array}{l}1885-1897 \\
1897-1906 \\
1906-1913\end{array}$ & $\begin{array}{l}+181 \\
+205 \\
+287\end{array}$ & $\begin{array}{l}-142 \\
-161 \\
-216\end{array}$ & $\begin{array}{r}-27 \\
-62 \\
-117\end{array}$ & $\begin{array}{l}-47 \\
-107 \\
-197\end{array}$ & $\begin{array}{l}-35 \\
-125 \\
-243\end{array}$ \\
\hline
\end{tabular}

ancludes repatriated profits.

Sources: Column 2: see table 1. Columns 3-5: Paul Gregory, "The Russian Balance of Payments, the Gold Standard, and Monetary Policy: A Historical Example of Foreign Capital Movements," Journal of Economic History, 39, no. 2 (June 1979).

surplus during the three periods. Although no particular claim is made concerning the accuracy of the various service items (table 2, columns 3-5), the likelihood of significant errors in measurement is small. It is obvious that in all three periods public and private debt service obligations alone virtually cancel out the positive merchandise balance, and no one denies that net tourist expenditures were substantial.

There is a second way to calculate the Russian balance of payments. Until now, my analysis has been based upon the "indirect" measure of the payments balance, compiled by adding the merchandise and service balances. The payments balance can also be estimated directly by examining net changes in foreign indebtedness and gold reserves. Although the direct estimates are based on data that are less reliable than the indirect estimates reported in table $2,{ }^{28}$ they provide strong support for the conventional interpretation of the Russian balance of payments. Russia remained a net borrower abroad throughout the period investigated. In fact, Russia's foreign borrowing grew dramatically throughout the period 18851913.

In this note, I have attempted to show that Sontag's and Miller's contention - that the postive Russian merchandise balance was grossly understated by the Ministry of Finance-is incorrect. First, there is no strong evidence that the customs valuation of imports and exports was systematically biased. Second, comparisons of the trade statistics of other countries with those of the Russian authorities fail to support the understatement hypothesis because of several statistical shortcomings. Consequently, scholars must return to the traditional view that Russia continued to receive inflows of foreign savings throughout the late nineteenth and early twentieth centuries. Moreover, these flows increased as a percentage of the merchandise balance throughout the period, and Russia's dependence upon European capital markets therefore increased during Russia's gold standard years. Sontag's description of tsarist Russia as a country emancipating itself from dependence upon borrowing in Berlin and Paris and free to pursue a foreign policy independent of foreign borrowing considerations is inaccurate.

28. See Gregory, "The Russian Balance of Payments, the Gold Standard, and Monetary Policy." 